\title{
Tietoa toimintatutkimuksesta tutkivalla otteella
}

Heikkinen, Hannu L.T., Rovio, Esa \& Syrjälä, Leena (toim. 2006) Toiminnasta tietoon. Toimintatutkimuksen menetelmät ja lähestymistavat. Kansanvalistusseura.

Toimintatutkimus on laaja sateenvarjotermi, jonka voi katsoa sisältävän erilaisia osallistavia ja toimintasuuntautuneita lähestymistapoja sosiaaliseen muutokseen ja sen tutkimiseen. Aikuiskasvatuksen näkökulmasta se on tapa tutkimuksellisesti tarkastella muutosta, kehittämistä, interventioita, sosiaalisia suhteita ja rakenteita, yhteiskunnallista tiedonmuodostusta yms. varsin kompleksista ja muuntuvaa ilmiötä, jota muutoin olisi mahdotonta pelkistää yksinomaan dokumenttien, havainnoinnin, haastattelun tai kyselyn avulla selviteltäväksi tai kuvattavaksi ilmiöksi.

Heikkisen, Rovion ja Syrjälän toimittamassa kirjassa "Toiminnasta tietoon" selvitellään toimintatutkimusta ja sen toteuttamista perusasioita läpikäyvällä otteella, jota voisi luonnehtia tutkivaksikin. Toimintatutkimuksesta on melko vähän kirjoitettu suomenkielistä tutkimusmenetelmäkirjallisuutta, joten käsillä oleva Kansanvalistusseuran julkaisema teos on osaltaan paikkaamassa tätä puutetta. Kirjassa esitellään toimintatutkimuksen eri puolia kolmessa pääluvussa, joissa käsitellään lähtökohtia ja suuntauksia, käytäntöä sekä toimintatutkimuksen arviointia ja taustalla olevia käsityksiä tieteellisen tiedon luonteesta ja tietämisestä.

Toimintatutkimusta on kirjassa pyritty määrittämään muuta- mien kuvaavien käsitteiden avulla kuten interventioon perustuva, käytännönläheinen, osallistava, reflektiivinen tai sosiaalinen prosessi. Nämä varmasti luonnehtivat toimintatutkimusta. Listaan olisi yhtä hyvin voinut lisätä muitakin määrityksiä, millä kuvata toimintatutkimusta, kuten dialoginen, transformatiivinen, syklinen, prosessuaalinen. Yhtä ainoaa tai tyhjentävää tapaa kuvata monimuotoista tutkivaa prosessia ei oikeastaan ole. Kuten kirjassa oivallisesti todetaan, postmoderni ajattelu kyseenalaistaa suuret kertomukset ja tällaisissa uusissa tutkimusotteissa tietämisen, estetiikan ja etiikan väliset rajat sumenevat.

\section{Toimijoiden osallisuus}

Yleisesti toimintatutkimuksen eri tulkinnoissa on löydettävissä eroja siinä, mitä näkökohtia toimintatutkimuksessa pidetään tärkeinä. Suomalaisessa kirjallisuudessa hyvin usein lähtökohtana on ollut Carrin ja Kemmisin edustama ajattelutapa, jossa korostetaan toimintatutkimukseen osallistuvien toimijoiden osallisuutta, reflektiota ja demokraattista dialogia. Toinen keskeinen lähtökohta on ollut viittaaminen toimintatutkimuksen niin sanottuun oppi-isään Kurt Lewiniin. Lewinistä ja hänen tunnetuksi tekemästä kenttäteoriastaan nytkin käsillä olevassa kirjassa läh- detään liikkeelle. Varsinaisia toimintatutkimuksellisia nykysuuntauksia kirjassa esitellään lyhyesti useampia: kriittinen toimintatutkimus, osallistava toimintatutkimus, tutkiva opettaja -liike, toimintatiede ja kommunikatiivinen suuntaus. Tämä on hyvä ratkaisu ja tuo toimintatutkimuksen laajaa kenttää esille, vaikkakin nykysuuntaukset käydään läpi melko suppeasti. Iso osa toimintatutkimusta toteutetaan kansainvälisten julkaisujen perusteella opetuksellisissa tilanteissa. Tämä liittyy opettajavetoiseen kehittämistoimintaan, jota on korostettu tutkivan opettajuuden tyyppisissä ideoissa.

Erityiseksi ansioksi kirjassa voi laskea kahden toimintatutkimusta lähellä olevan ajankohtaisen suuntauksen esille tuomisen - kehittävän työntutkimuksen ja design-tutkimuksen - jotka istuttavat kirjan hyvin tähän päivään. Näiltä osin kirja toimiikin oppikirjana ja lähdeteoksena toimintatutkimuksen erilaisiin variaatioihin. Lukijan kannalta on siis hyvä, että esille on otettu muitakin suuntia kuin mainitut Carrin ja Kemmisin klassikkonäkemykset, mitkä kriittiseen toimintatutkimukseen liittyvät.

\section{Aikuiskasvatus ja työelä- mä tutkimusalueina}

Aikuiskasvatuksen näkökulmasta muun muassa aikuiskoulutus, työelämä ja vapaa sivistystyö hahmottuvat tärkeinä tutkimusalueina - myös toimintatutkimuksen. Varsinkin työelämäyhteyksissä erilaisista muutospro- 
sesseista ja muutoksen hallinnasta on tullut kehittämistyön mantra, jota toistetaan eri yhteyksissä. Monet toimintatutkimuksenkin edustajat korostavat toimintatutkimusta työn ja yhteisöjen kehittämisen välineenä. Toimintatutkimuksen näkökulmasta muutos - sen lähtökohdat ja tavoitteet, kenen etuja tavoitellaan ja millaisia ovat eri toimijoiden vaikuttamismahdollisuudet muutoksen suunnille näyttäytyy tärkeänä. Interventioiden ja muutoksen problematiikkaa olisi kirjassa voinut avata enemmänkin - myös kriittisestä näkökulmasta. Nämä näkökulmat jäävät kirjassa vähäiselle huomiolle johtuen todennäköisesti kirjoittajien omista tutkimusalueista ja painotuksista. Toimintatutkimuksen kenttätyön kohdalla olisi kaivannut muitakin kuin opettajakoulutukseen ja koulumaailmaan liittyviä esimerkkejä.

Toimintatutkimuksen yksi kriittinen kohta on tutkimuksen raportointi. Toimintatutkimus ehkä vaatii muita menetelmiä runsaammin tutkijan tekemien valintojen perusteluja ja toiminnan aukikirjoittamista. On hyvä muistaa, että toimintatutkimus liikkuu sillä rajapinnalla, missä vaarana on joko etääntyä tieteellisestä tiedosta tai etääntyä itse toiminnasta. Heikkisen ja Rovion kirjoittamassa osuudessa ratkaisuna on ollut verrata toimintatutkimuksen raportointia narratiiviseen tutkimukseen, toisin sanoen tarinalliseen ja juonelliseen kerrontatapaan. Tämä vie tutkimuksellista ajattelua vahvasti siihen suuntaan, että tutkimuksella myös tuotetaan todellisuutta. Tutkijasta tulee kertoja ja kertomuksella luodaan todellisuutta, jopa erilaisia todellisuuksia erilaisille yleisöille.
Narratiivinen ote sinänsä sopii toimintatutkimusraporttiin, mutta ehkä tässä kohdin olisi voinut pohtia hieman myös muita mahdollisia vaihtoehtoja perinteiselle paradigmaattiselle tieteellisen kirjoittamisen raportointitavalle.

\section{Toimintatutkimus ja totuudellisuus}

Toimintatutkimuskaan ei ole vallasta tai vaikuttamisesta vapaata toimintaa. Siksi onkin tärkeää, että kirjaan on otettu mukaan myös toimintatutkimuksen totuutta koskeva luku. Mielenkiintoinen tietoteoreettinen ratkaisu on sitoa kirjassa toimintatutkimustiedon tarkastelu konstruktivistiseen paradigmaan (s.164165). Tieto (tai tietäminen) tästä näkökulmasta katsottuna on yksilöllisen tai sosiaalisen konstruktioprosessin tulosta. Tämä lähtökohta korostaa toimijoiden keskinäisen merkitysneuvottelun ja aikaansaadun prosessin osuutta toimintatutkimuksessa. Mutta jäävätkö silloin vuorovaikutuksen kontekstiin liittyvät tekijät, kuten valta-asetelmat, institutionalisoituneet käytännöt, toimijoiden roolit ja positiot, vallitseva toimintakulttuuri yms. tekijät liian vähälle huomiolle? Toimintatutkimuksessahan usein tulee esille myös erilaisia ristiriitoja ja jännitteitä, mitkä liittyvät erityisesti siihen kontekstiin, missä tutkija ja toimintaan osallistuvat toimivat. Konstruktivistinen tietoteoria on sinänsä kirjassa esitetty hyvin laveana ja erilaisia suuntia - kuten kriittisiä valtaa koskevia - sisäänsä sulkevana. Mutta ihmettelevälle lukijalle tulee eittämättä mieleen, eikö yhtä oikein olisi tarkastella toimintatutkimusta myös kriittisen teorian tai interaktionistisen paradigman kautta, mitkä voisivat antaa enemmän aineksia läpivalaista sosiaalisessa vuorovaikutuksessa syntyneiden tulkintojen kontekstuaalisia taustatekijöitä.

\section{Toimintatutkimuksen oh- jaus}

Kirjoittajia on mukana ollut peräti kolmetoista, joiden kautta on tullut hyvin erilaisia tulokulmia toimintatutkimukseen. Tämä ei ole tehnyt kirjasta liian sirpalemaista luettavaa, vaan juoni ja ote säilyvät ehyinä alusta loppuun. Mielenkiintoinen ja tuore näkökulma kirjassa on toimintatutkimuksen ohjaaminen (kirjoittajatiiminä Rovio, Klemola, Lautamatti ja Tiihonen), mitä ehkä harvemmin tuodaan esille. Toimintatutkimusprosessithan ovat toteutustavoiltaan kompleksisia ja edellyttävät yhteistyötä käytännön toimijoiden kanssa. Toimintatutkimuksen rinnastus ohjausprosessiin on kuitenkin tehty kirjassa hieman kömpelösti, sillä lukija ei aina oikein ole varma, tarkoittaako termi tutkija ja ohjaaja tekstissä samaa vai eri henkilöä? Käytännössä tilanne voi olla se, että tutkija ja ohjaaja ovat eri henkilöitä, mutta usein voi lähtökohta olla myös se, että tutkija myös itse ohjaa toimintatutkimuksen kulkua. Tällainen tutkijan ja ohjaajan suhdetta selkiyttävä määritys on nyt jäänyt tekstistä puuttumaan.

Kokonaisuutena ottaen teos on kuitenkin hyvä katsaus toimintatutkimukselliseen lähestymistapaan ja taustalla oleviin tietoa koskeviin käsityksiin. Tietyt näkökulmavalinnat ja painotukset teoksessa näkyvät, mikä ei kuitenkaan vähennä kirjan käyttökelpoisuutta oppikirjana tai alan lähdekirjana. Viimei- 
sessä kirjan päättävässä tekstissä Heikkinen ja Huttunen kirjoittavat toimintatutkimuksen luonteesta (s. 200): "se on asenne tai mielentila, joka perustuu toiminnan kehittämiseen tutkimuksen avulla ja tiedon hankkimiseen toiminnan kehittämi- sen avulla". Kirja ei pyri olemaan perinteinen ohjeita antava metodikirja, joten sitä voi lämpimästi suositella lukijalle, joka kaipaa kotimaista alueen perusteosta johdattelemaan toimintatutkimuksellisen ajattelun äärelle. Kehittämistä, muutosta tai muutoksen tutkimista ei problematisoida, mutta tämä ei liene perusoppikirjan tehtäväkään.

\section{Vesa A.Korhonen}

